\title{
DESAIN KAWASAN AGROEDU-WISATA BERBASIS DESA
}

\section{Hermin Werdiningsih ${ }^{1}$ ) Muhammad Ismail Hasan ${ }^{1,2 *}$ ) Previari Umi Pramesti ${ }^{1}$ )}

*) Corresponding author email : $\underline{\text { bva190016@siswa.um.edu.my }}$

1)Sekolah Vokasi, Universitas Diponegoro

2)Architecture, Faculty of Built Environment, University of Malaya

\begin{tabular}{l}
\hline Article info \\
MODUL vol 20 no 1, issues period 2020 \\
\hline Doi $\quad: 10.14710 /$ mdl.20.1.2020.44-48 \\
Received $: 24$ januari 2020 \\
Revised $: 17$ maret 2020 \\
Accepted $: 28$ maret 2020
\end{tabular}

\section{Abstrak}

Pengembangan pariwisata berbasis desa sedang marak dikembangkan di desa-desa. Terlebih pariwisata memberikan dampak baik yang cukup signifikan untuk penguatan perekonomian serta pemberdayaan masyarakat desa. Konsep wisata yang cocok diterapkan di desa adalah konsep wisata yang mengusung kelokalan seperti agrowisata karena pertanian sangat lekat kaitannya dengan pedesaan. Untuk menambah nilai wisata itu sendiri, konsep edukasi juga perlu ditambahkan untuk mengenalkan pertanian bagi pengunjungnya. Konsep wisata tersebut yang dirancang di Desa Lopait untuk memberikan manfaat tanah bengkok sekaligus mengangkat perekonomian wara sekitar. Desain yang dikembangkan berkonsep murah, mudah, dan tidak bersifat permanen, sehingga sebagian besar infrastrukturnya menggunakan bambu.

Keywords: wisata; agroeduwisata; desa

\section{Pendahuluan}

Salah satu pembangunan yang sedang gencar dilakukan adalah merintis objek wisata di desa. Perkembangan pariwisata pedesaan juga digalakan oleh pemerintah karena merupakan investasi jangka panjang yang potensial karena sumber daya baik alam maupun manusia telah tersedia (Komariah, et al., 2018). Pengembangan pariwisata di pedesaan juga dimaksudkan untuk memberdayakan masyarakat dengan melibatkan sumber daya sekitar yang dimiliki untuk kemudian dikemas secara menarik dan disajikan sebagai sebuah objek wisata (Herawati, et al., 2018). Selain itu pengembangan pariwisata di pedesaan merupakan salah satu cara efektif mengurangi kesan kumuh. Hal ini dikarenakan dengan adanya objek wisata di daerah tersebut akan mendorong masyarakat sekitar untuk menjaga kebersihan lingkungannya (Sesotyaningtyas \& Manaf, 2015).

Terkait pariwisata di pedesaan, hendaknya dapat mendukung budaya lokal atau akan lebih baik lagi bila dapat mengembalikan budaya agraris yang mulai ditinggalkan. Konsep pariwisata berbasis pertanian sangat cocok untuk dikembangkan di pedesaan terlebih negara kita terkenal akan budaya agraris (Sumantra, et al., 2017). Objek wisata yang menggabungkan potensi pertanian dan konsep pariwisata disebut agro-wisata (Satriawan, et al., 2015). Pengambangan agrowisata di pedesaan juga dapat menjadi sarana edukasi dibidang pertanian baik bagi warga sekitar maupun masyarakat luas (Budiarti, et al., 2013). Sarana edukasi yang ditawarkan konsep agrowisata juga dapat diperdalam lagi sehingga menjadi salah satu konsep utama dari pariwisata ini. Pada dasarnya wisata edukasi merupakan wisata yang bernilai positif dimana konsep pariwisata ini memadukan kegiatan pembelajaran dengan wisata (Priyanto, et al., 2018). Dalam kasus ini pembelajaran yang akan ditawarkan adalah mengenai pertanian sehingga konsep pariwisata ini dapt disebut agroedu wisata.

Desa Lopait merupakan sebuah desa di Kecamatan Tuntang, Kabupaten Semarang yang pertumbuhan ekonominya tergolong cukup baik. Hal ini didukung oleh lokasinya yang sangat strategis, yakni dilewati oleh jalan nasional yang menghubungkan Semarang dan Solo. Sebagaimana desa pada umumnya, Desa Lopait memiliki lahan yang digunakan sebagai gaji para perangkat desanya. Salah satu lahan milik Sekertaris Desa rencananya akan digunakan untuk dikembangkan menjadi lokasi wisata. Untuk saat ini tanah bengkok hanya ditanami tanaman buah-buahan dan sayuran dan kondisi tanahnya cukup subur. Letak tanah bengkok tepat berada di belakang Saloka Park yang merupakan tempat wisata baru di Jawa Tengah. 
Lokasi tanah bengkok cukup strategis karena terlihat dari tempat parkir Saloka Park dan terdapat akses dari tempat parkir menuju lahan bengkok tersebut. Dari potensi-potensi diatas, tanah bengkok tersebut akan lebih bernilai secara ekonomis bila tidak hanya dimanfaatkan sebagai pertanian, namun juga sebagai lokasi wisata berbasis pertanian dan edukasi. Tujuan dari penelitian ini adalah untuk menemukan desain agroedu wisata yang cocok untuk diterapkan di lahan bengkok Desa Lopait.

\section{Metode \& Langkah Penelitian}

Dalam penelitian ini, metode penelitian yang digunakan adalah kualitatif karena bertujuan untuk memahami fenomena pada subjek penelitian secara holistik kemudian mendeskripsikannya dengan metode alamiah (Moleong, 2011). Terkait hal tersebut, penggunaan metode kualitatif sangat tepat karena desa wisata melibatkan banyak pihak seperti stakeholder, masyarakat sekitar, dan pengunjung. Lebih lanjut strategi studi kasus akan melengkapi metode penelitian ini. Dalam strategi studi kasus, peneliti menyelidiki suatu program, kejadian, proses, atau sekelompok individu (Harsritanto, 2018). Studi kasus digunakan karena dapat memahami makna dari permasalahan yang bersumber dari sosial yang melibatkan partisipan dan mendapatkan data yang spesifik (Creswell, 2013). Sumber-sumber yang digunakan dalam studi kasus diantaranya : dokumentasi, rekaman arsip, wawancara, observasi langsung, observasi partisipan, dan perangkat fisik (Yin, 2014).

\section{i. Dokumentasi}

Penelitian ini membutuhkan dokumentasi baik primer berupa foto-foto saat kunjungan ke lokasi penelitian dan dukungan data eksisting mengenai lokasi atau data sekunder (Nasution, 2000). Dokumentasi yang diperlukan terkait penelitian ini adalah foto mengenai lahan serta kondisi sekitarnya

ii. Rekaman Arsip

Rekam arsip didapatkan dari siteplan lahan yang akan direncanakan sebagai objek wisata tersebut. Karena belum ada data mengenai gambar siteplan lahan, maka peneliti membuat gambar siteplan berdasarkan survey pada langkah dokumentasi.

iii. Wawancara

Tahapan ini membutuhkan perangkat desa yang berkepentingan terhadap lahan bengkok tersebut. Data yang dibutuhkan mengenai potensi lahan terhadap pertanian, peraturan penggunaan lahan bengkok terhadap penggunaannya sebagai pariwisata, hingga keterlibatan masyarakat sekitar terhadap pariwisata ini.

iv. Observasi Langsung
Pada tahapan ini, peneliti mengunjungi lokasi secara langsung untuk mendapatkan pengalaman sebagai stakeholder, masyarakat sekitar, hingga pengunjung lokasi wisata.

\section{Temuan Lapangan}

Dari hasil survey, didapatkan beberapa data menganai lahan, diantaranya :

1. Sebagian lahan telah ditanami berbagai macam tanaman sayur dan buah

2. Lahan berkontur

3. Memiliki potensi view dari Saloka Park namun terhalang pagar yang cukup tinggi

4. Pengembangan di tanah bengkok tidak diperbolehkan membangun bangunan permanen

5. Desain harus murah dan easy maintenance

Pada Peraturan Menteri Pariwisata Republik Indonesia Nomor 3 Tahun 2018 (Pariwisata, 2018) tentang Petunjuk Operasional Pengelolaan Dana Alokasi Khusus Fisik Bidang Pariwisata, disebutkan bahwa Pengembangan Daya Tarik Wisata sebagai upaya peningkatan kualitas fasilitas daya tarik wisata, mencakup :

1. Pembangunan pusat informasi wisata / TIC (Tourism Information Center) dan perlengkapannya;

2. Pembuatan ruang ganti dan/atau toilet;

3. Pembuatan pergola;

4. Pembuatan gazebo;

5. Pemasangan lampu taman;

6. Pembuatan pagar pembatas;

7. Pembangunan panggung kesenian/pertunjukan;

8. Pembangunan kios cenderamata;

9. Pembangunan plaza / pusat jajanan kuliner;

10. Pembangunan tempat ibadah;

11. Pembangunan menara pandang(viewing deck);

12. Pembangunan gapuraidentitas;

13. Pembuatan jalur pejalan kaki (pedestrian)/jalan setapak/jalan dalam kawasan, boardwalk, dan tempat parkir; dan

14. Pembuatan rambu-rambu petunjuk arah.

\section{Analisa Hasil Survey}

Dari hasil survey, dapat dihasilkan beberapa respon yang akan dijadikan guidelines dalam desain, berikut responnya :

1. Sebagian lahan yang telah ditanami sayuran dan buah-buahan akan tetap difungsikan sebagaimana fungsi awalnya. Sebagian lahan tersebut juga difungsikan sebagai area edukasi pertanian.

2. Lahan akan dibiarkan berkontur dan seminal mungkin dilakukan cut and fill untuk mengurangi biaya penggalian dan pengurugan. 
3. Letak lahan yang berada di belakang Saloka Park dapat dijadikan sebuah potensi, yakni view taman bermain yang menarik. Akan tetapi view tersebut terhalang pagar yang cukup tinggi, maka dari itu dibuatlah semacam jembatan memanjang (sky bridge) di atas area pertanian untuk dapat menikmati view Saloka Park. Selain itu dari sky bridge pengunjung dapat menikmati view pedesaan, persawahan, bahkan Rawa Pening.

4. Sebagian besar infrastruktur di objek wisata didesain menggunakan bambu. Hanya beberapa bangunan saja yng menggunakan batu bata, seperti toilet. Bambu dipilih karena material ini ramah lingkungan serta kekuatannya dapat diandalkan (Suriani, 2017) (Sukawi, 2010).

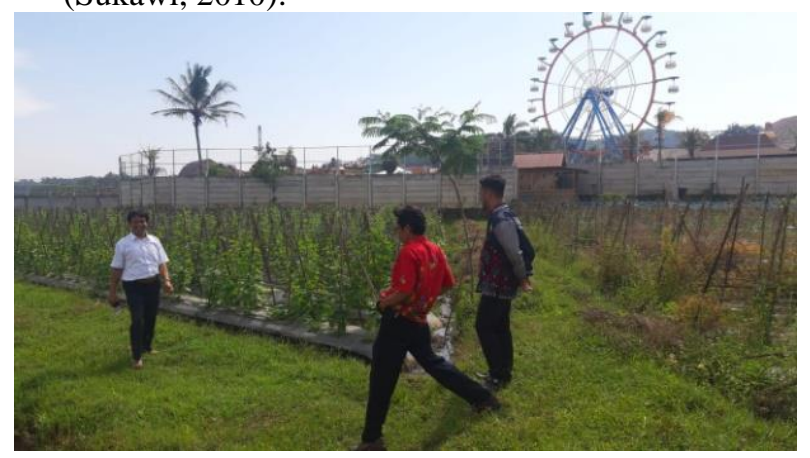

Gambar 1. Letak site berada tepat di belakang Saloka Park, selain itu telah ditanami beberapa macam tanaman. (Sumber: Penulis, 2019)

Secara singkat, temuan lapangan, analisa, dan respon dapat dilihat dalam tabel berikut :

\begin{tabular}{|c|c|c|}
\hline Temuan & Analisa & Respon \\
\hline $\begin{array}{l}\text { Sebagian } \\
\text { lahan telah } \\
\text { ditanami }\end{array}$ & $\begin{array}{l}\text { Fungsi lahan tetap } \\
\text { dipertahankan dan } \\
\text { akan ditambahkan } \\
\text { lagi fungsinya } \\
\text { yakni } \\
\text { wisata sebagai } \\
\text { pertanian }\end{array}$ & $\begin{array}{lr}\text { Memilih } & \text { tanaman } \\
\text { yang } & \text { mudah } \\
\text { perawatan } & \text { dan } \\
\text { cepat } & \text { berbuah } \\
\text { untuk } & \text { kemudahan } \\
\text { sarana } & \text { edukasi } \\
\text { kepada pengunjung }\end{array}$ \\
\hline $\begin{array}{l}\text { Lahan } \\
\text { berkontur }\end{array}$ & $\begin{array}{l}\text { Kondisi eksisting } \\
\text { dipertahankan }\end{array}$ & $\begin{array}{lr}\text { Meminimalkan cut } \\
\text { and fill guna } \\
\text { mengurangi biaya } \\
\text { gali dan urug, } \\
\text { selain itu lahan } \\
\text { berkontur } \\
\text { memberikan } & \\
\text { alami. } & \end{array}$ \\
\hline $\begin{array}{l}\text { Memiliki } \\
\text { view Saloka } \\
\text { Park }\end{array}$ & $\begin{array}{lr}\text { Saloka } & \text { Park } \\
\text { dijadikan } & \text { potensi } \\
\text { yang } & \text { menarik } \\
\text { tanpa } & \text { harus } \\
\text { membangun } & \\
\text { infrastruktur yang }\end{array}$ & $\begin{array}{l}\text { Memanfaatkan view } \\
\text { Saloka Park dapat } \\
\text { memberikan nilai } \\
\text { tambah bagi objek } \\
\text { wisata ini tanpa } \\
\text { harus membangun }\end{array}$ \\
\hline
\end{tabular}

$$
\text { banyak }
$$

Bangunan

harus semi permanen, murah, \& mudah perawatan
Status lahan yang merupakan Tanah Bengkok mengharuskan pemanfaatannya bukan untuk bangunan permanen

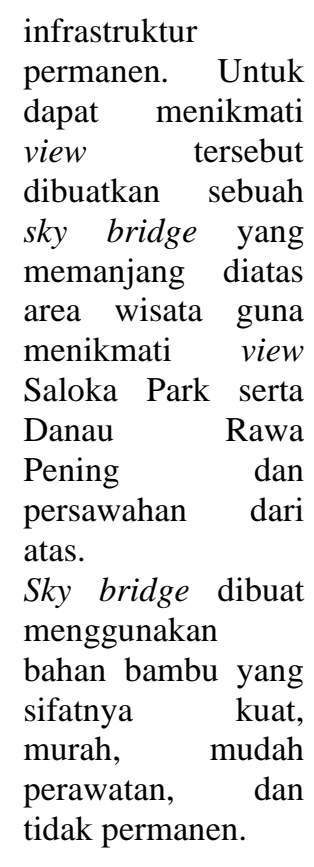

infrastruktur permanen. Untuk dapat menikmati view tersebut dibuatkan sebuah sky bridge yang memanjang diatas area wisata guna menikmati view Saloka Park serta Danau Rawa Pening dan persawahan dari

menggunakan

bahan bambu yang sifatnya kuat, perawatan, dan tidak permanen.

Berdasarkan Peraturan Menteri Pariwisata Republik Indonesia Nomor 3 Tahun 2018 tentang Petunjuk Operasional Pengelolaan Dana Alokasi Khusus Fisik Bidang Pariwisata, selain area pertanian, edukasi, serta sky bridge diperlukan pula sarana penunjang kawasan wisata. Sarana penunjang diantaranya : akomodasi, tempat makan dan minum, tempat belanja, dan fasilitas umum. Fasilitas umum diantaranya tempat parkir, toilet, musholla, sarana penggerak di lokasi wisata, sarana informasi dan signage, sarana rekreasi dan taman bermain, serta telepon umum (Fajriah \& Mussadun, 2014). Akomodasi dalam hal ini tidak direncanakan untuk dibangun di kawasan ini terkait aturan lahan yang tidak memungkinkan untuk dibangun bangunan permanen. Sehingga sarana yang direncanakan diantaranya tempat makan dan minum, tempat belanja, serta fasilitas umum. Kemudian untuk fasilitas umum yang memungkinkan dibangun di kawasan ini mencakup : tempat parkir, toilet, musholla, sarana informasi, dan sarana rekreasi 


\section{Rekomendasi Desain}

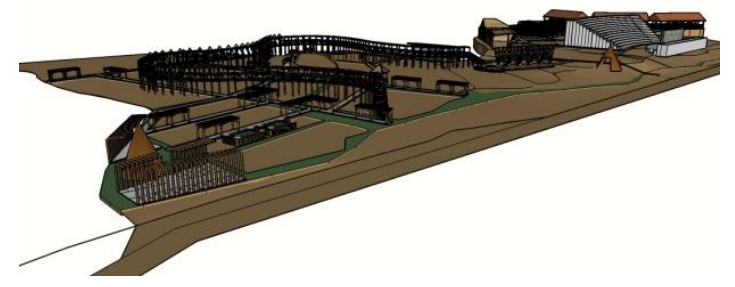

Gambar 2. Siteplan perencanaan lokasi wisata

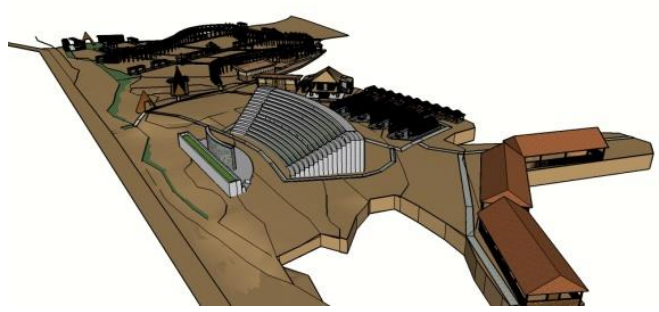

Gambar 3. Siteplan perencanaan lokasi wisata

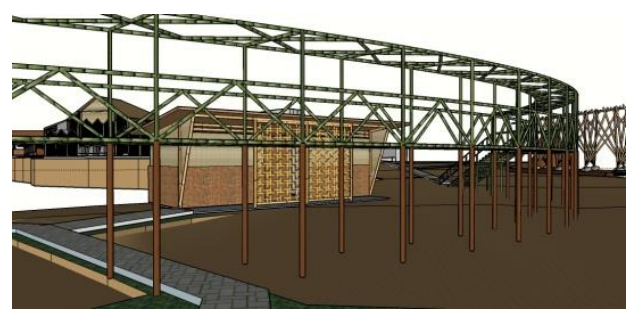

Gambar 4. Sky bridge

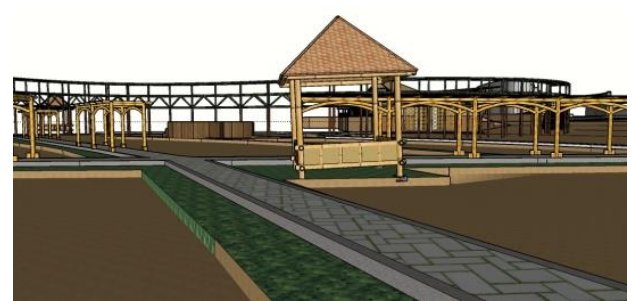

Gambar 5. Sky bridge dan gazebo

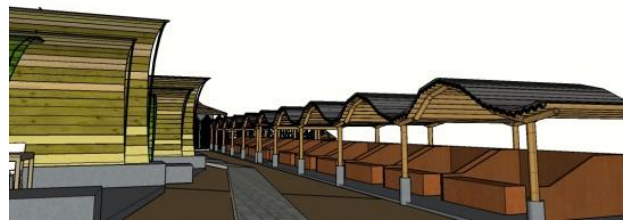

Gambar 6. Pujasera dan tempat penjualan souvenir

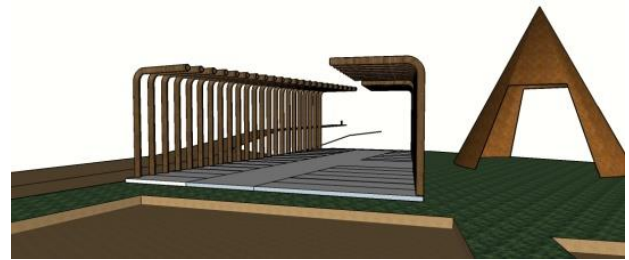

Gambar 7. Are parkir

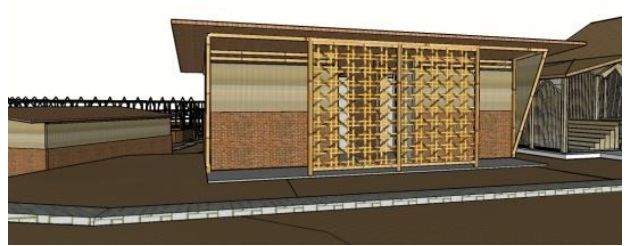

Gambar 8. Toilet

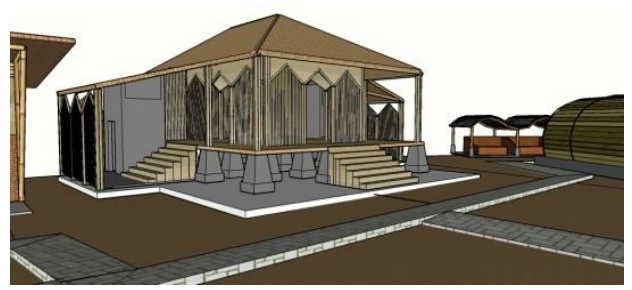

Gambar 9. Musholla

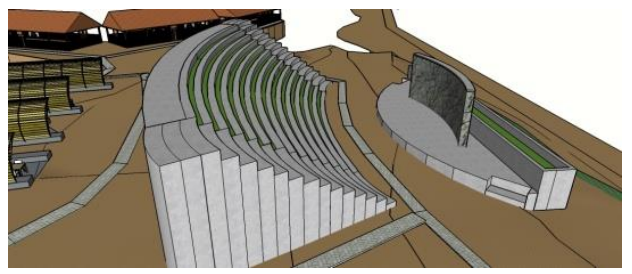

Gambar 10. Sarana rekreasi berupa teater terbuka untuk pertunjukan kesenian lokal

\section{Kesimpulan}

Lahan bengkok milik Perangkat Desa Lopait yang sebelumnya hanya dimanfaatkan untuk pertanian, sangat cocok untuk dikembangkan sebagai objek pariwisata. Pemanfaataan lahan yang sebelumnya berupa pertanian dapat menjadi dasar tema wisata tersebut yakni agrowisata sekaligus edukasi, sehingga dapat disebut agro-eduwisata. Untuk menunjang pariwisata, diperlukan pula perancangan kawasan yang matang, menarik, namun sesuai aturan. Penggunaan bambu pun menjadi alternatif desain yang mendukung 
lokalitas, ramah lingkungan, serta bersifat tidak permanen mengingat status lahan bengkok yang tidak diperuntukkan untuk bangunan permanen.

\section{Daftar Pustaka}

Budiarti, T., Suwarto \& Muflikhati, I. (2013) Pengembangan Agrowisata Berbasis Masyarakat pada Usahatani Terpadu guna Meningkatkan Kesejahteraan Petani dan Keberlanjutan Sistem Pertanian. Jurnal Ilmu Pertanian Indonesia, 18(3), pp. 20-207.

Creswell, J. W. (2013) Research Design Pendekatan Kualitatif, Kuantitatif, dan Mixed. 3 ed. Yogyakarta: Pustaka pelajar.

Fajriah, S. D. \& Mussadun (2014) Pengembangan Sarana dan Prasarana untuk Mendukung Pariwisata Pantai yang Berkelanjutan (Studi Kasus : Kawasan Pesisir Pantai Wonokerto Kabupaten Pekalongan). Jurnal Pembangunan Wilayah \& Kota, 10(2), p. 218.

Harsritanto, B.I.R. et al. 2018. Study of Outdoor Thermal Comfort in Old City Openspace, Case Study Semarang Old City. Advanced Science Letters, Vol. 24, 9548-9551

Herawati, A., Purwaningsih, A. \& Handharko, Y. D., (2018) Promoting Village Tourism through the Development of Information System. Review of Integrative Business \& Economics Research, 7(1), p. 221.

Kementrian Pariwisata (2018) Petunjuk Operasional Pengelolaan Dana Alokasi Khusus Fisik Bidang Pariwisata. Peraturan Menteri Pariwisata. Jakarta: Kementrian Pariwisata.

Komariah, N., Saepudin, E. \& Rodiah, S., (2018) Development of Tourist Village Based on Local Wisdom. Journal of Environmental Management and Tourism, 9(6), pp. 1172-1177.

Moleong, L. J., (2011) Metodologi Penelitian Kualitatif. 29 ed. Bandung: Rosda.

Nasution, S., (2000) Metode Research : Penelitian Ilmiah. Jakarta: Bumi Aksara.

Priyanto, R., Syarifuddin, D. \& Martina, S., (2018) Perancangan Model Wisata Edukasi di Objek Wisata Kampung Tulip. Jurnal Abdimas BSI, pp. 32-38.

Satriawan, I. K., Pujaastawa, I. B. G. \& Sarjana, I. M., (2015) Development of Small-scale Agrotourism in Province of Bali, Indonesia. Advances in Environmental Biology, 9(21), pp. 9-14.

Sesotyaningtyas, M. \& Manaf, A., (2015) Analysis of Sustainable Tourism Village Development at Kutoharjo Village, Kendal Regency of Central
Java. Rocedia Social and Behavioral Sciences, Volume 184, pp. 273-280.

Sukawi, (2010) Bambu Sebagai Alternatif Bahan Bangunan dan Konstruksi di Daerah Rawan Gempa. Jurnal TERAS, X(1).

Sumantra, I. K., Yuesti, A. \& Sudiana, A. K., (2017) Development of Agrotourism to Support Community-Based Tourism toward Sustainable Agriculture. Australian Journal of Basic and Applied Sciences, 11(13), pp. 93-99.

Suriani, E., (2017) Bambu Sebagai Alternatif Penerapan Material Ekologis : Potensi dan Tantangannya. EMARA, 3(1), p. 33.

Yin, R. K., 2014. Studi Kasus Desain \& Metode. Depok: Rajagrafindo Persada. 